\title{
EVALUATION OF INITIAL GAS VOLUME OF COALBED METHANE USING FOUR METHOD
}

\author{
Heri Susanto ${ }^{1, a}$, Karen Sondakh¹, Ratnayu Sitaresmi ${ }^{1, b}$, Ryodi Hananda ${ }^{1}$ \\ ${ }^{1}$ Faculty of Tecnhology of Earth and Energy - TrisaktiUniversity \\ aherisusanto10@rocketmail.com, br_sitaresmi@yahoo.com
}

\begin{abstract}
Coal bed methane (CBM) is an unconventional energy resources in which the main ingredient is methane gas formed in the process of formation of coal (coalification). Based on research Advance Resource International inc. (ARI), the CBM resource potential is $453 \mathrm{Tcf}$ spread across 11 basins in Indonesia. CBM technology is expected to be one of the alternative energy can play a role in helping to suppress the natural gas needs of oil as one of the energy commodities di Indonesia.

This paper discusses about a calculated initial volume of gas in place (Gas in Place) on CBM reservoir " $X$ " field. This initial gas volume calculation first calculating the gas content is becoming an important parameter in calculating the initial volume. This content gas value can be obtained through data analysis proximate such as ash content, moisture content, volatile matter, fixed carbon which such data can be obtained from laboratory results. But there is also the calculation of the gas content which can be obtained by simply using coal density data using several methods of calculation, such as the Mavor method, Bambang, Modified Kim, and Mullen method. In the " $\mathrm{X}$ " field there are five wells coalbed methane drilling has been done, namely, SS-1, SS-2, SS 3, SS-4 and SS-5 and there are five layers are seam-1, seam-2, seam3 , seam-4, and seam-5. Based on the calculations were also obtained in the " $\mathrm{X}$ " field coal rank, the average is sub-bitminous. Of the five wells will be calculated gas content and the initial volume of gas using a method Mavor, Bambang, Modified Kim, and Mullen.

Using four methods then the gas content in the SS well ranged between 200-500 SCF / ton. And assuming that the well drainage area (A) covering an area of 100 acres, the obtained large volumes of coal bed methane wells SS-1 with the four methods ranged from 3-9 BSCF, the SS-2 ranged between 1-3 BSCF, wells SS- 3 are 2-5 BSCF, the SS-4 range between 1-3 BSCF and the SS-5 ranges between 1-3 BSCF.

We will be compared the initial gas volume in the Field " $X$ " using the four methods with data from the laboratory result. From that analysis it can be proved that the Bambang method is the most suitable method and represents CBM field in Indonesia. So the initial gas volume in Field " $X$ " is using the result from Bambang method, and the result are 5312.17 MMscf on the SS-1well, 2385.77 MMscf on the SS-2 well, 3330.84 MMscf on the SS-3 well, 1635.44 MMscf on the SS-4 well, and 1608.74 MMscf on the SS-5 well. And the total initial gas volume in the "X" Field is 14273 MMSCF.
\end{abstract}

Keywords : coal rank, gas content, initial volume gas in place, coal bed methane

\begin{abstract}
Abstrak
Coal bed methane (CBM) adalah sumber energi yang tidak konvensional di mana bahan utamanya adalah gas metana yang terbentuk dalam proses pembentukan batubara (coalification). Berdasarkan penelitian Advance Resource International inc. (ARI), potensi sumber daya CBM adalah 453 Tcf yang tersebar di 11 cekungan di Indonesia. Teknologi CBM diharapkan menjadi salah satu energi alternatif yang dapat berperan dalam membantu menekan kebutuhan gas alam minyak sebagai salah satu komoditas energi di Indonesia.

Makalah ini membahas tentang perhitungan volume awal gas di tempat (Gas di Tempat) di lapangan $C B M$ reservoir " $X$ ". Perhitungan volume gas awal ini yang pertama menghitung kandungan gas menjadi parameter penting dalam menghitung volume awal. Nilai gas isi ini dapat diperoleh melalui analisis data langsung seperti kadar abu, kadar air, bahan mudah menguap, karbon tetap yang data tersebut dapat diperoleh dari hasil laboratorium. Tetapi ada juga perhitungan kandungan gas yang dapat diperoleh dengan hanya menggunakan data kepadatan batubara menggunakan beberapa metode perhitungan, seperti metode Mavor, Bambang, Modified Kim, dan metode Mullen. Di lapangan "X" telah dilakukan lima sumur pengeboran metana batubara, yaitu, SS-1, SS-2, SS 3, SS-4 dan SS-5 dan ada lima lapisan yaitu jahitan-1, jahitan-2 , jahitan-3, jahitan-4, dan jahitan-5. Berdasarkan perhitungan juga diperoleh dalam peringkat
\end{abstract}


batubara lapangan " $X$ ", rata-rata adalah sub-bitminous. Dari lima sumur tersebut akan dihitung kandungan gas dan volume awal gas menggunakan metode Mavor, Bambang, Modified Kim, dan Mullen.

Dengan menggunakan empat metode, maka kandungan gas di sumur SS berkisar antara 200-500 SCF / ton. Dan dengan asumsi bahwa area drainase sumur (A) seluas 100 acre, diperoleh sumur metana coal bed volume besar SS-1 dengan empat metode berkisar antara 3-9 BSCF, SS-2 berkisar antara 1-3 BSCF , sumur SS-3 adalah 2-5 BSCF, kisaran SS-4 antara 1-3 BSCF dan rentang SS-5 antara 1-3 BSCF.

Kami akan membandingkan volume gas awal di Lapangan " $X$ " menggunakan empat metode dengan data dari hasil laboratorium. Dari analisis itu dapat dibuktikan bahwa metode Bambang adalah metode yang paling cocok dan mewakili bidang CBM di Indonesia. Jadi volume gas awal di Lapangan " $X$ " menggunakan hasil dari metode Bambang, dan hasilnya adalah 5312,17 MMscf pada sumur SS-1well, 2385,77 MMscf pada sumur SS-2, 3330,84 MMscf pada sumur SS-3, 1635,44 MMscf pada sumur SS-4, dan 1608,74 MMscf pada sumur SS-5. Dan total volume gas awal di Lapangan "X" adalah 14273 MMSCF.

Kata kunci: peringkat batubara, kandungan gas, volume gas awal di tempat, metana unggun batubara

\section{BACKGROUND}

Coal methane gas (CBM) is an unconventional energy resource which the main composition is methane gas formed in the process of coal formation (coalification) Coal Bed Methane (CBM) or methane gas is a methane gas trapped in a coal micropore due to a thermogenic or biogenic process and is associated with coal. Methane is a non-toxic gas that is tasteless, odorless and colorless. Methane is a major element of natural gas that is about $80 \%$ to $98 \%$ natural gas. At first this methane is often regarded as a danger and high risk in coal mining because it is explosive or burning. Along with the development of science and development of economic aspects, coal methane gas is now widely produced for use in energy and fuel supplies.

Based on Advance Resource International research inc. (ARI), CBM resource potential of $453 \mathrm{Tcf}$ spread over 11 basins throughout Indonesia. Its areas are basin of South Sumatera (183 Tcf), Barito (101,6 Tcf), Kutei (89,4 Tcf) and Central Sumatra (52,5 Tcf) for high prospective category. The Tarakan Basin (17.5 Tcf), Berau (8.4 Tcf), Ombilin (0.5 Tcf), Sand / Acid (3.0 Tcf) and Jatibarang $(0.8 \mathrm{Tcf})$ have the modarate prospective category. While the Sulawesi basin $(2.0 \mathrm{Tcf})$ and Bengkulu (3.6 Tcf) are categorized as low prospective. CBM technology is expected to be one of the alternative energy that can play a role in helping natural gas suppress oil needs as one of the energy commodities in Indonesia.

\section{BASIC THEORY}

III.

\section{Proximate Analysis}

Proximate Coal Analysis is used to determine the characteristics and quality of coal in relation to the use of coal, namely to determine the relative amount of moisture content, volatile matter, ash and contain carbon In coal. This proximate analysis is the most fundamental test in determining the quality of coal.

\section{Coal Rank}

Coal rank is the parameter of production success and the amount of reserves that have from a coal bed methane (CBM) field. This is because the coal rank implies potential gas content, permeability, and physical and mechanical properties of coal. The rank of these coal may vary laterally or vertically within a coal seam and may also vary between each seam in a coal group. Generally, to determine the quality of coal, chemical analysis of coal is used, such as proximate analysis.

Coal at bituminous rank is the most sought and most preferred coal in coal bed methane (CBM) exploitation because the physical properties and mechanical properties of coal are at optimum levels. Specifically, bituminous to sub-bituminous bituminous coal is best for CBM reservoirs. More gas contained in this rating during the maturation process and gas storage capabilities is also increasing. 
Generally, the standard coal-scale parameter parameters that are often found in coal bed methane (CBM) projects can be seen in Table 2.1 (Appendix)

\section{Ash Content}

Ash content (ash) is defined as the organic matter left behind after the coal sample is incinerated under standard conditions until a fixed weight is obtained. The ash content is measured by burning in a furnace at a temperature of $815^{\circ} \mathrm{C}$. The residue formed is ash from coal.

\section{Moisture Content}

In coal, moisture content $(\mathrm{m})$ comprises at least one single chemical compound. The form may be in the form of water that can flow rapidly from within a coal sample, an adsorbed compound, or as a chemically bonded compound. Some moisture is a component of mineral substances that are not bound to coal.

\section{Volatile Matter}

Volatile Matter (VM) is the amount of substance lost when the coal sample is heated at a predetermined temperature and time (after being corrected by the moisture content). The temperature is $900 \mathrm{oC}$, with a precise seven-minute warm-up time.

\section{Fixed Carbon}

Fixed carbon (FC) represents the amount of carbon contained within

Waste material after volatile matter is removed.

\section{Gas Content}

One of the determinants of the amount of initial gas content in place in the CBM reservoir is the gas content (gas content). Gas content itself is the amount of gas in the coal matrix. There are several methods for determining the gas content, the difference in yields of each method can lead to differences in the final gas volume in place.

\section{Mavor et al}

The Mavor, close, McBane or Mavor et al equation is the equation used to calculate the gas content by using ash dried base (ad). This formula has a constant value determined by Mavor et al., Based on the results of laboratory studies on Sample enough to get enough data representative, so the formula as follows:

$G c=601,4-751,8$ ad

ad $=\frac{V_{A}}{1-V_{M}}$

The ash content and moisture data used is the data obtained from the results of the proximate analysis in the laboratory. In general, this equation can be used for proximate calculations. The equations Mavor shows are:

$V_{A}=64,94 \times \rho_{b}-66,27$

$V_{F C}=-0,517 \times V_{A}+51,2$

$V_{M}=-0,1 \times V_{A}+4,61$

$V_{V M}=100-V_{A}-V_{F C}-V_{M}$

The bulk density $(\mathrm{\rho b})$ parameter used is the data parameter obtained from the analysis of each seam of laboratory data on each well.

\section{Bambang A.W. et al}

Equation Mavor et.al. Has a drawback to apply to the existing CBM reservoir in Indonesia due to the different coal types. Therefore, Bambang A.W et.al. Conducted a study to obtain a sufficient representative equation for use in the CBM reservoir in Indonesia. The equations are: 
$V_{F C}=-0,4729 \times V_{A}+35,965$

$V_{M}=-0,1 \times V_{A}+20,63$

$G c=314,08-70,263$ ad

\section{Modified Kim}

This method is used to calculate the gas content based on the original equation of Kim in the modification. The use of modified kim's equations requires several data parameters: pressure, temperature, and proximate. These data parameters are needed to find the values of $\mathrm{k} 0$ and $\mathrm{n} 0$. The modified kim equation is written as follows:

$G c=\frac{(100-m-a)}{100} \times \frac{V w}{V d} \times\left(K^{0} \times 0.96(h)^{n^{0}}-b \frac{1.8 h}{100}+11\right)$

$\frac{V w}{V d}=0.75$

$K_{0}=0,8 \times\left(V_{F c} / V_{M}\right)+5,6$

$n_{0}=0,39-0,1 \times\left(V_{F c} / V_{M}\right)$

$\mathrm{Gc}=\mathrm{m}^{3}$ ton $\mathrm{x} 32.0368$

\section{Metode Mullen}

Mullen in its equation connects the average density of coal with the gas content. For Equations are as follows:

$G c=-542 \rho_{b}+1053$

\section{GIP Calculation}

Calculation of initial gas volume in place by using gas content calculated by various methods. The use of some gas content calculation methods is intended to compare the initial volume of gas in place with different gas content calculation methods. The calculation of the initial gas volume in place is carried out using the Mavor and Nelson equations as follows:

$G I P=1359,7 \times(A \times h) \times G c \times \rho_{b} \times(1-(a+m))$

\section{METODOLOGY}

In this study, there are four main steps taken to obtain evaluation and analysis of the final calculation results are:

1. Calculation of ash content, moisture content, volatile matter, and fixed carbon

2. Coal Rank Determination based on calculation data

3. Gas content calculation using 4 methods

4. Calculation of initial gas volume in coal seam using Mavor and Nelson method

There are 109 coal core samples conducted by laboratory test, 5 wells and 5 seam which is calculated in this study for evaluation and analysis. In each well the dispersion of seam is uneven, so that in the SS-3 well there is no seam-4, the SS-4 wells are not seam-1, seam-4, seam-5, and SS5 wells are not seam-1, Seam-4, seam-5. 


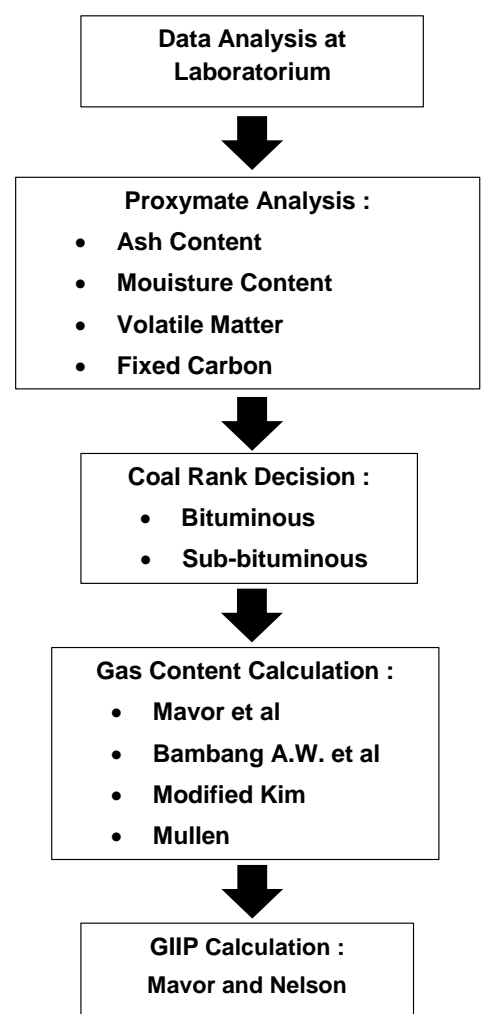

Figure 1

Workflow

\section{DATA ANALYSIS}

In this paper, the authors evaluate CBM reservoir laboratory data in the " $\mathrm{X}$ " field to account for the initial volume of gas present in it. Evaluation of initial gas volume is done by analyzing coal core samples contained in the laboratory, then compared with the result of initial gas volume with proximate analysis so that it can get the proximate analysis calculation method which closest to laboratory result. After the appropriate method obtained to calculate the initial volume of the gas, there is no need to do analysis of core samples in laboratories that are time consuming and costly. So to calculate the initial volume of CBM gas using only well logging data that is density log with data of coal density.

In this field, there are 5 layers of Seam-1, Seam-2, Seam-3, Seam-4, and Seam-5. Gas intial in place data obtained from the calculation using 4 methods of Mavor method, Bambang, Modified Kim, and Mullen.

\section{Coal Rank Decision}

Proximate analysis is performed to determine the ash content, moisture content, volatile matter and fixed carbon used for calculation of initial volume of gas and coal rank.

From the proximate analysis, dry ash, dry volatile, dry fixed carbon, and dry ash free volatile and dry ash free fixed carbon values are found. These results are then classified according to the coal rank tables of the American Society for Testing and Materials (ASTM, 1981, op cit Wood et al., 1983). (Appendix table 2.1).

From the data and tables it is known that each sample in each seam has a coal rank of high volatile bituminous A to subituminous, but dominated by subituminous. For more details, see attachment table 4.1-table 4.5.

\section{Gas Content}


To determine the initial volume of gas in a well, must be calculated Gas Content first. In SS-1 wells, gas content was obtained using Mavor et.al method ranging from $491 \mathrm{scf} /$ ton to $522 \mathrm{scf} /$ ton. By using the method Bambang gas content value ranges from $301 \mathrm{scf} /$ ton to $308 \mathrm{scf} / \mathrm{ton}$. Modified Kim ranges from $357 \mathrm{scf} /$ ton to $474 \mathrm{scf} /$ ton. The Mullen method ranges from $381 \mathrm{scf} /$ ton to $449 \mathrm{scf} /$ ton.

SS-2 well, obtained the calculation of gas content, using Mavor et.al method ranged from 451 scf / ton to $570 \mathrm{scf} /$ ton. By using Bambang method gas content value ranges from $297 \mathrm{scf} /$ ton to $310 \mathrm{scf} /$ ton. Modified Kim ranges from $341 \mathrm{scf} /$ ton to $416 \mathrm{scf} /$ ton. The Mullen method ranges from $338 \mathrm{scf} /$ ton to $466 \mathrm{scf} /$ ton.

The SS-3 well, obtained from gas content calculation, using Mavor et al., Ranged from 413 $\mathrm{scf} /$ ton to $545 \mathrm{scf} /$ ton. By using Bambang method, gas content value ranges from $293 \mathrm{scf} /$ ton to $307 \mathrm{scf} /$ ton. Modified Kim ranges from $289 \mathrm{scf} /$ ton to $455 \mathrm{scf} /$ ton. The Mullen method ranges from $296 \mathrm{scf} /$ ton to $440 \mathrm{scf} /$ ton.

SS-4 well, obtained from gas content calculation, using Mavor et.al method ranged from 344 $\mathrm{scf} /$ ton to $534 \mathrm{scf} / \mathrm{ton}$. By using the method Bambang gas content value ranges from $285 \mathrm{scf} /$ ton to $306 \mathrm{scf} /$ ton. Modified Kim ranges from $324 \mathrm{scf} /$ ton to $448 \mathrm{scf} /$ ton. The Mullen method ranges from $217 \mathrm{scf} /$ ton to $428 \mathrm{scf} /$ ton.

SS-5 well, obtained from gas content calculation, using Mavor et.al method ranged from 486 $\mathrm{scf} /$ ton to $496 \mathrm{scf} / \mathrm{t}$ ton. By using Bambang method gas content value ranges from $301 \mathrm{scf} /$ ton to $302 \mathrm{scf} /$ ton. Modified Kim ranges from $382 \mathrm{scf} /$ ton to $409 \mathrm{scf} /$ ton. The Mullen method ranges from $376 \mathrm{scf} /$ ton to $386 \mathrm{scf} /$ ton.

\section{Initial CBM Volume}

The initial gas volume at Field " $\mathrm{X}$ " is calculated using laboratory results data (Langmuir). As mentioned earlier, the calculation of the initial gas volume in place also uses four methods, namely the Mavor Method, Bambang Method, Kim Modified Method, and also the Mullen Method. These four methods are used as comparators of initial volume of calculated gas from laboratory data (Langmuir). And which will be analyzed which method is the result most closely to the initial volume calculation results with laboratory data. The initial volume of gas in Field X using laboratory data (Langmuir) on well SS-1 was obtained at 5245.66 MMScf, at SS-2 of 2678.96 MMScf, at SS-3 of 1600.35 MMScf, at SS-4 of 1195.62 MMScf, and At the SS-5 well of 1643.79 MMScf. The result of initial gas volume calculation by using Mavor method on SS-1 well is 9163.48 MMScf, SS-2 equal to 5318.53 MMScf, SS-3 of 2566.99 MMScf, and SS-5 of 2617.79 MMScf. Bambang's method obtained the initial gas volume value at SS-1 wells of 5312.17 MMScf, SS-2 wells of 2385.77 MMScf, SS-3 of 3330.84 MMScf, SS-4 of 1635.44 MMScf, and SS-5 wells of 1608.74 MMScf. The initial gas volume at Field X with Kim Modified method on SS-1 well is 7558.11 MMScf, SS-2 of 3551.02 MMScf, SS-3 of 4655.64 MMScf, SS-4 of 2219.69 MMscf, and SS-5 of 2105.43 MMScf .And by using Mullen method the initial gas volume in Field "X" at well SS-1 is 7310.51 MMScf, SS-2 of 3141.06 MMScf, SS-3 is 4084.41 MMScf, SS-4 1949.95 MMScf, and SS-5 well 2032.54 MMScf. The ratio of the initial gas volume to each method can be seen in the curve contained in the appendix. After the calculation on the four methods, it can be seen that Bambang's method is the closest to the data results from Laboratorium (Langmuir), this is because the formula in Bambang Method is a modification of the formula that is adjusted with CBM field in Indonesia. So through this calculation can prove that Bambang's method is very suitable and represents and can be applied to any CBM field in Indonesia. 


\section{CONCLUSION}

Based on the results of this study, it can be concluded as follows:

- Coal rank on "X" field in seam-1 to 5 seams is dominated by subbituminous coal rank.

- Calculation of gas content and initial gas volume is done using 4 (four) methods of equation, namely: Mavor et.al., Bambang A.W. Et.al., modified Kim, and Mullen. Mavor et al. Does not match the type of coal characteristic in Indonesia. Bambang A.W.'s reformulation method Et.al. More suitable because it is modified in accordance with the characteristics of the field and coal in the archipelago country of Indonesia.

- The smallest value of gas content is gas content using Bambang method that is ranging from $285 \mathrm{Scf} / \mathrm{t}$ to $310 \mathrm{Scf} / \mathrm{t}$.

- Initial gas volume values in the nearest field data were Bambang's method, at SS-1 wells of 5312.17 MMScf, SS-2 wells of 2385.77 MMScf, SS-3 of 3330.84 MMScf, SS-4 of 1635.44 MMScf, and SS-5 wells of 1608.74 MMScf.

\section{Recommendation}

Suggestions for this research in the future is to test the existing equations of various methods with the condition of coal bed methane reservoir more so, in getting more accurate comparison results and can be used as a guide in calculating the initial volume of CBM gas, especially in various Region in Indonesia.

\section{REFERENCES}

1. Divisi ESDM, "Peluang Investasi Sektor ESDM", Kementerian ESDM, Jakarta, 2010.

2. Halliburton," Coal Bed Methane: Principles and Practices",Texas, 2008.

3. Bambang, A.W.et.al., "Modifikasi Persamaan Proximate Log", Lembaran Publikasi LEMIGAS, Jakarta, 2010

4. Hidayat.2012 "Evaluasi Gas Content Menggunakan Berbagai Macam Metode untuk Menentukan Isi Awal Gas di Tempat Pada Lapangan Coal Bed Methane "RESA" . Tugas Akhir, Jurusan Teknik Perminyakan Universitas Trisakti, Jakarta

5. Simorangkir, Tiffani A. 2014" Analisis Proximate, Analisis ultimate dan Analisis Miscellaneous Pada Batubara". Tugas Akhir, Jurusan Teknik Pertambangan, ITM, Medan

6. Anpradino, Fallen F.2016 "Evaluasi Gas Content dengan menganalisis data laboratorium untuk menentukan isi awal gas pada reservoir cbm lapangan x" Tugas Akhir, Jurusan Teknik Perminyakan Universitas Trisakti, Jakarta

7. Unicorn in the garden of good and evil : Part 3 - Coal Bed Methane (CBM) By E.R.(Ross) Crain, P.Eng https://www.spec2000.net/freepubs/2010-3UnconvCBM.pdf [04 Nov 2016]

8. Digital Formation, Lesa, Coalbed Methane Log Analysis. Prepare by MichaelHolmes. http://www.creategeo.com/bgmanage/updown/2Upload\%20Files\%5CCBM.pdf [04 Nov 2016]

9. CBM reservoir http://petrowiki.org/CBM_reservoir_fundamentals [04 Nov 2016]

10. Coal Bed Methane http://www.cbmasia.ca/What-Is-CBM [04 Nov 2016]

\section{SYMBOL}

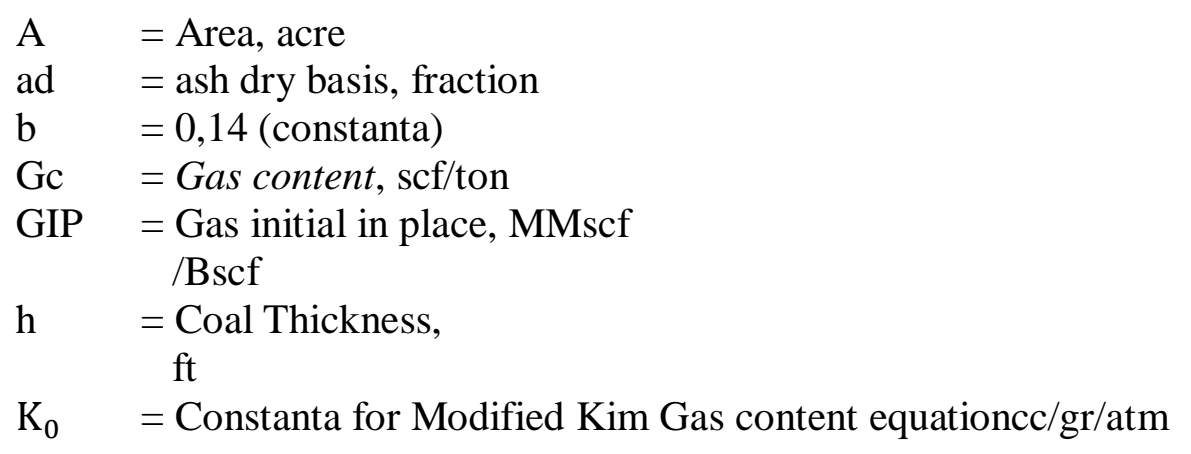


Journal of Mechanical Engineering and Mechatronics

ISSN: 2527-6212, Vol. 3 No. 1

(C) 2018 Pres Univ Press Publication, Indonesia

$\mathrm{m} \quad=$ moisture content, $\%$, fraction

$\mathrm{n}_{0} \quad=$ Constanta for Modified Kim Gas content equation, fraction

$\mathrm{P} \quad=$ Pressure, $(\mathrm{atm})$

$\rho_{\mathrm{b}} \quad=$ Average Coal Density, gr/cc

$\mathrm{T} \quad=$ Temperature, $\left({ }^{\circ} \mathrm{C}\right)$

$\mathrm{V}_{\mathrm{A}}=$ Ash content, $\%$, fraction

$\mathrm{V}_{\mathrm{d}} \quad=$ Gas volume at dry coal, dimensionless

$\mathrm{Vw}=$ Gas volume at moisture coal, dimensionless

$\mathrm{V}_{\mathrm{FC}} \quad=$ Fixed carbon, $\%$, fraction

$\mathrm{V}_{\mathrm{m}}=$ Moisture content, $\%$, fraction

$\mathrm{V}_{\mathrm{VM}}=$ Volatile matter, $\%$, fraction

Appendix

Table 1

Standard Size Parameter Coal Rank Determinants

\begin{tabular}{|l|l|l|l|l|}
\hline Class/group & Rank & $\begin{array}{l}\text { Volatile } \\
\text { Matter }(\%)\end{array}$ & $\begin{array}{l}\text { Fixed } \\
\text { Carbon } \\
(\% \text { daf })\end{array}$ & $\begin{array}{l}\text { Carbon } \\
\text { Content } \\
(\% \text { daf })\end{array}$ \\
\hline \multirow{4}{*}{ Anthracite } & an (anthracite) & $2-8$ & $>92$ & $>92$ \\
\cline { 2 - 5 } & sa (Semianthracite) & $8-14$ & $86-92$ & $91-92$ \\
\hline \multirow{5}{*}{ Bituminous } & Lvb (Low Volatile) & $14-22$ & $78-86$ & $89-91$ \\
\cline { 2 - 5 } & Mvb (Medium Volatile) & $22-31$ & $69-78$ & $86-89$ \\
\cline { 2 - 5 } & hvAb( High Volatile A) & $31-39$ & $<69$ & $81-86$ \\
\cline { 2 - 5 } & hvBb (High Volatile B) & $39-42$ & & $76-81$ \\
\cline { 2 - 5 } & hvCb (High Volatile C) & $12-47$ & & $66-76$ \\
\hline Subbituminous & Sub & $>47$ & & $<66$ \\
\hline
\end{tabular}

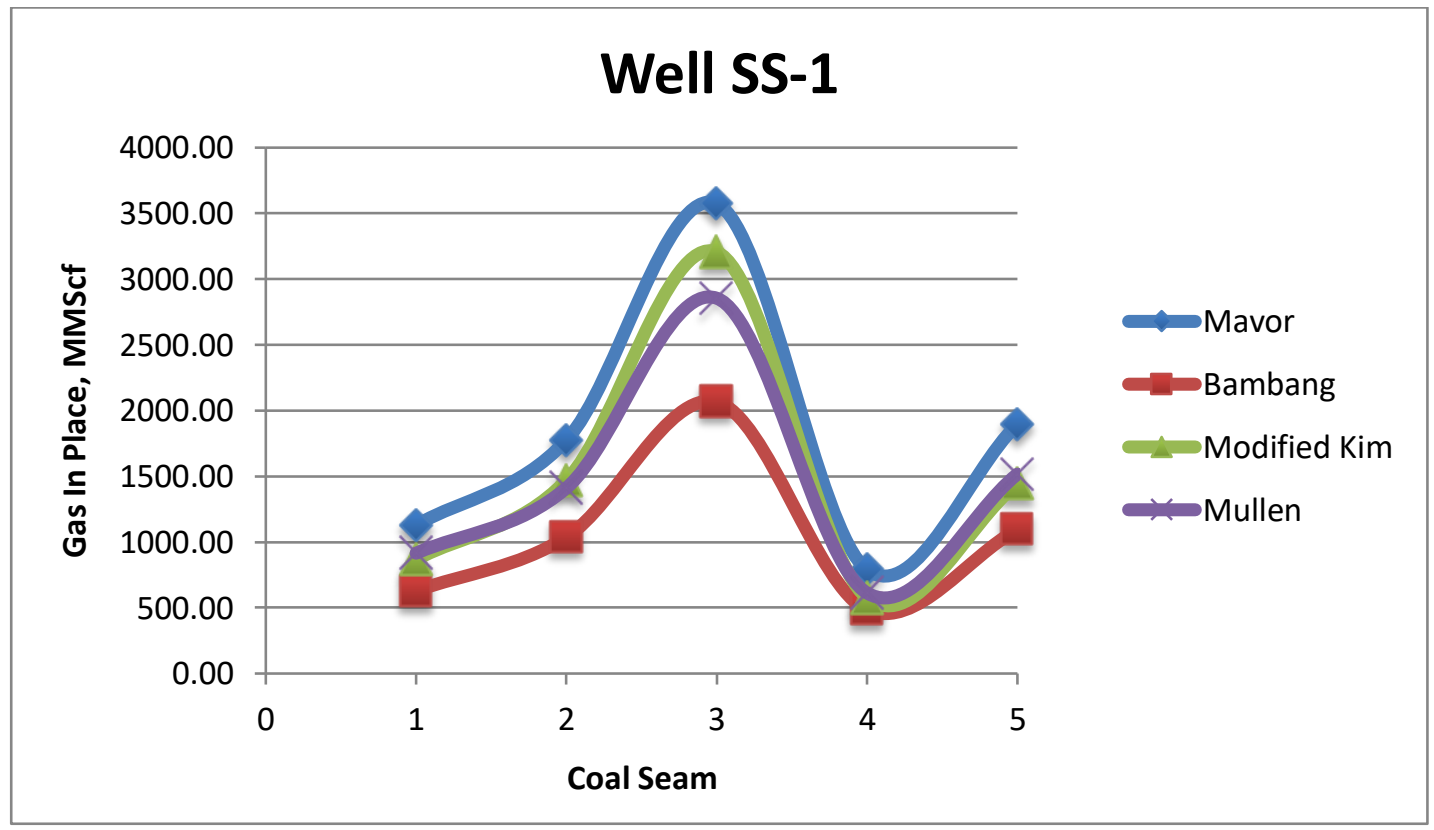

Fig. 1 
Journal of Mechanical Engineering and Mechatronics

ISSN: 2527-6212, Vol. 3 No. 1

(C) 2018 Pres Univ Press Publication, Indonesia

GIP comparison at SS-1 wells

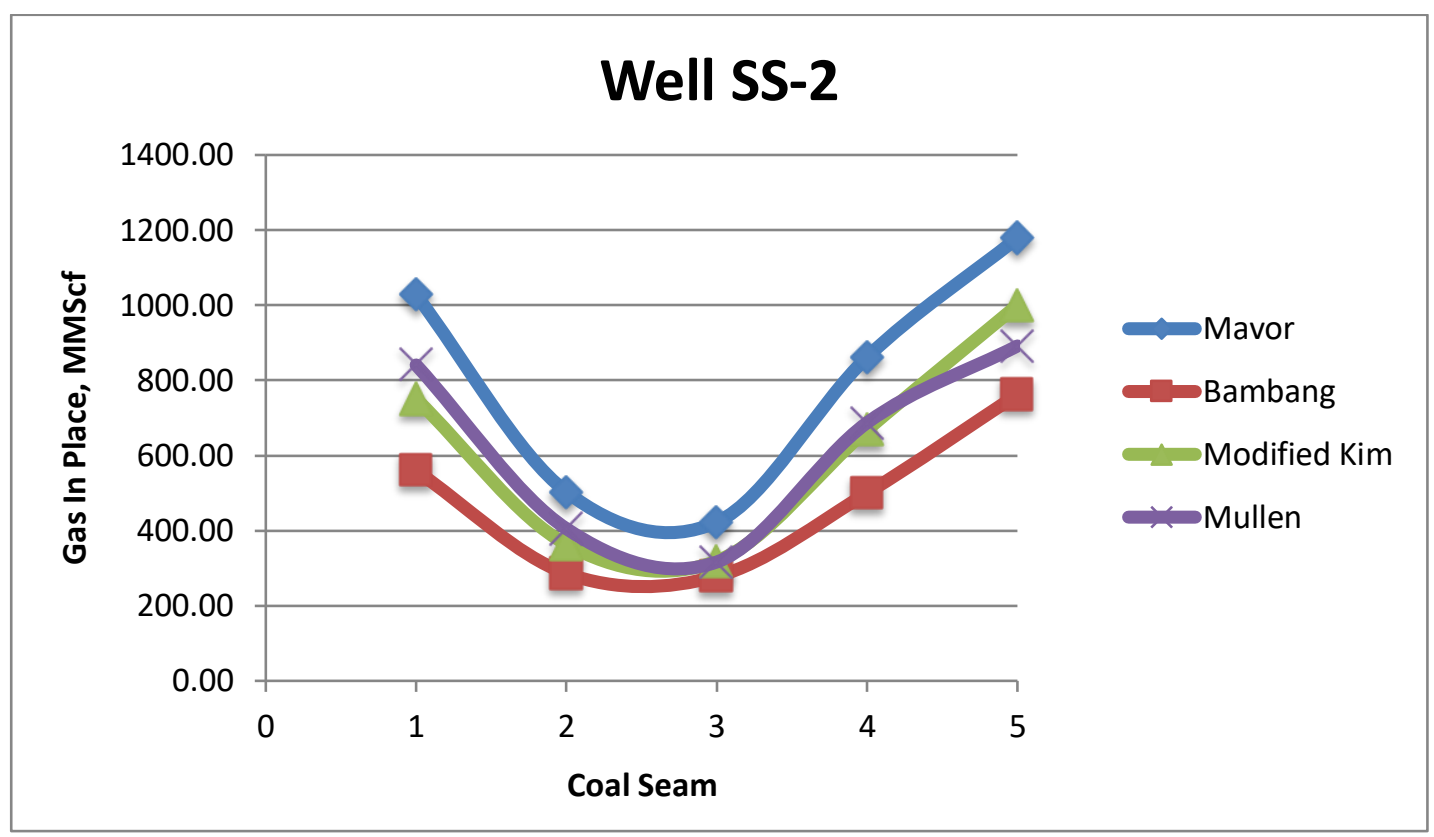

Fig. 2

GIP comparison at SS-2 wells

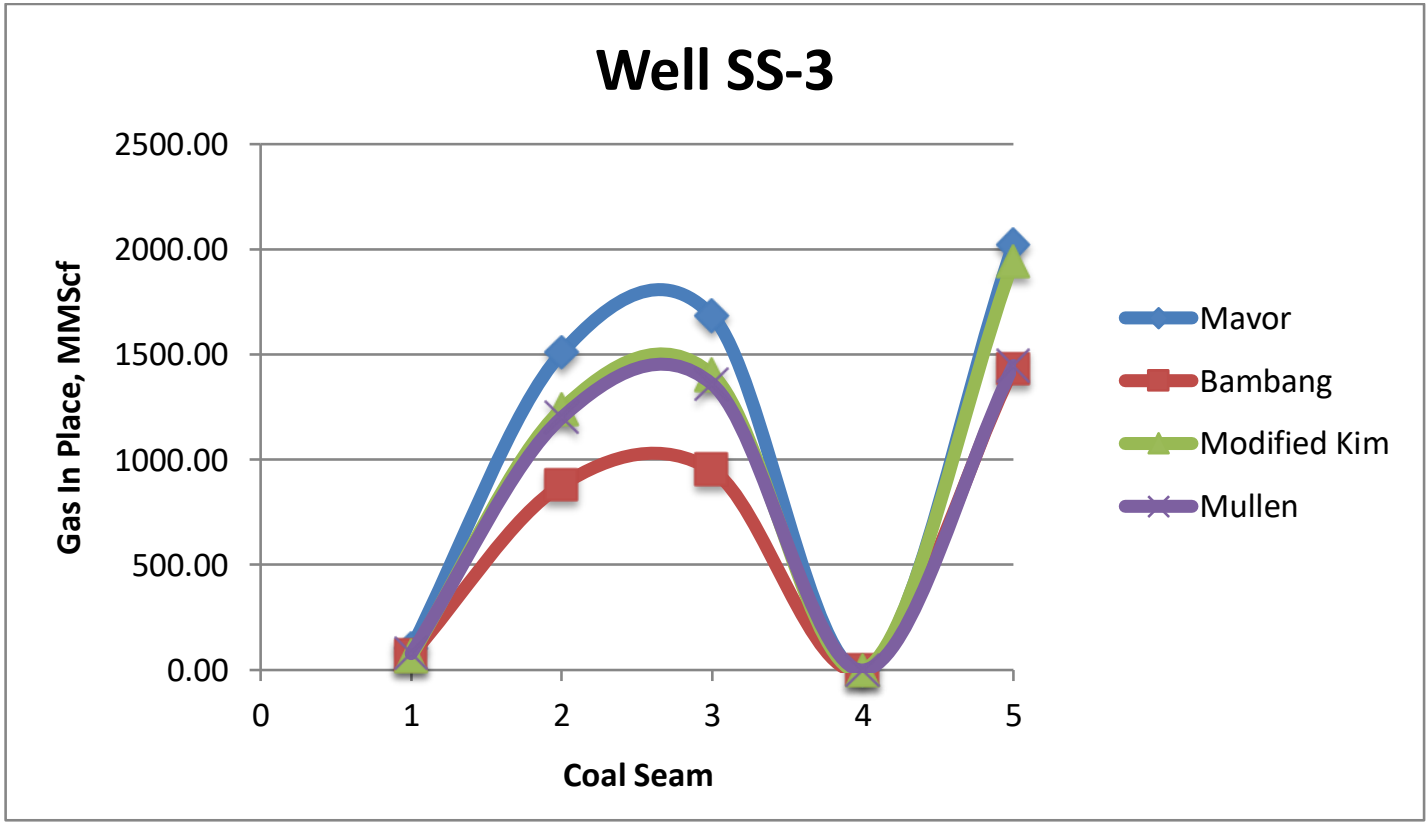

Fig. 3 
Journal of Mechanical Engineering and Mechatronics

ISSN: 2527-6212, Vol. 3 No. 1

(C) 2018 Pres Univ Press Publication, Indonesia

GIP comparison at SS-3 wells

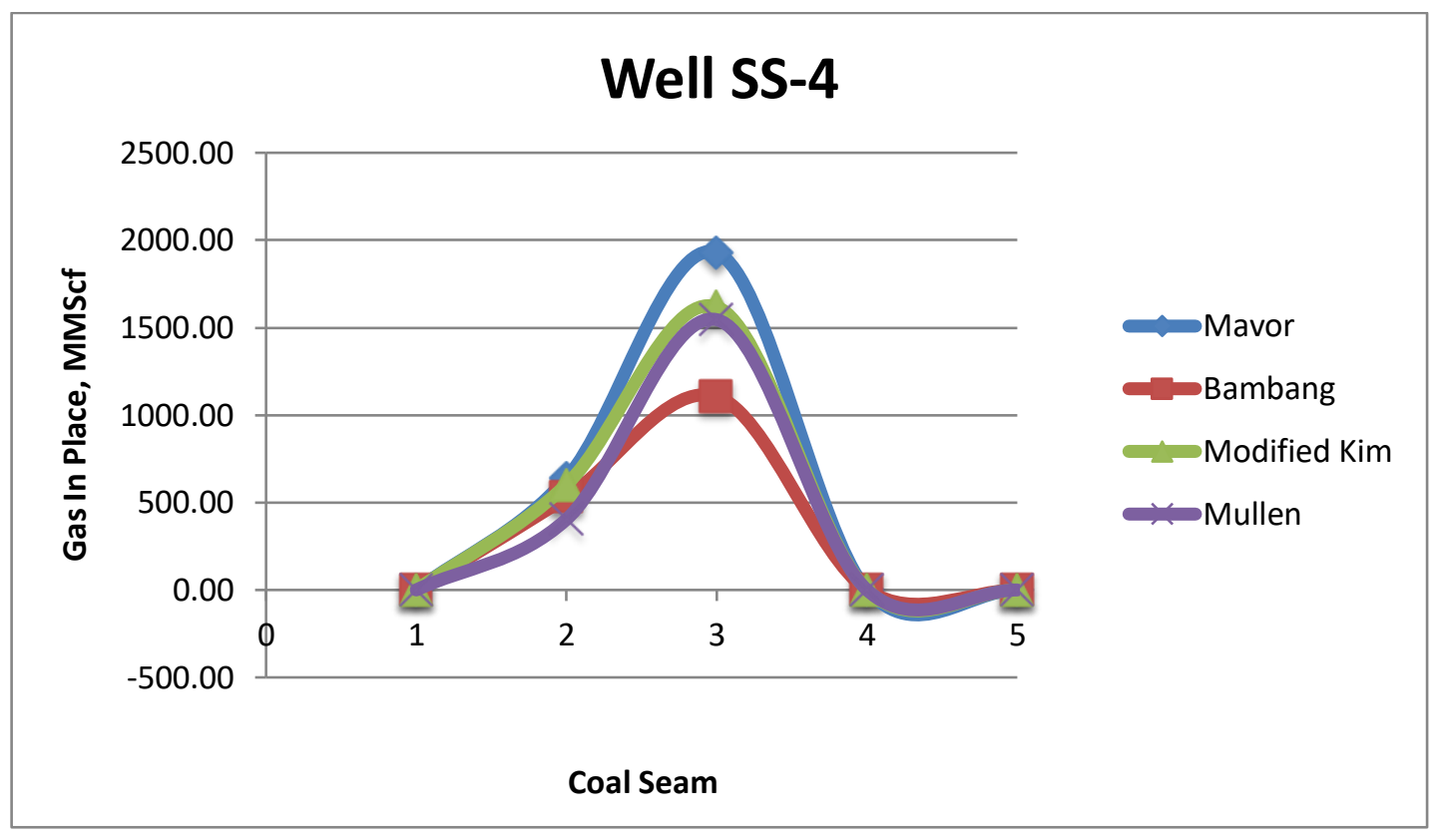

Fig. 4

GIP comparison at SS-4 wells

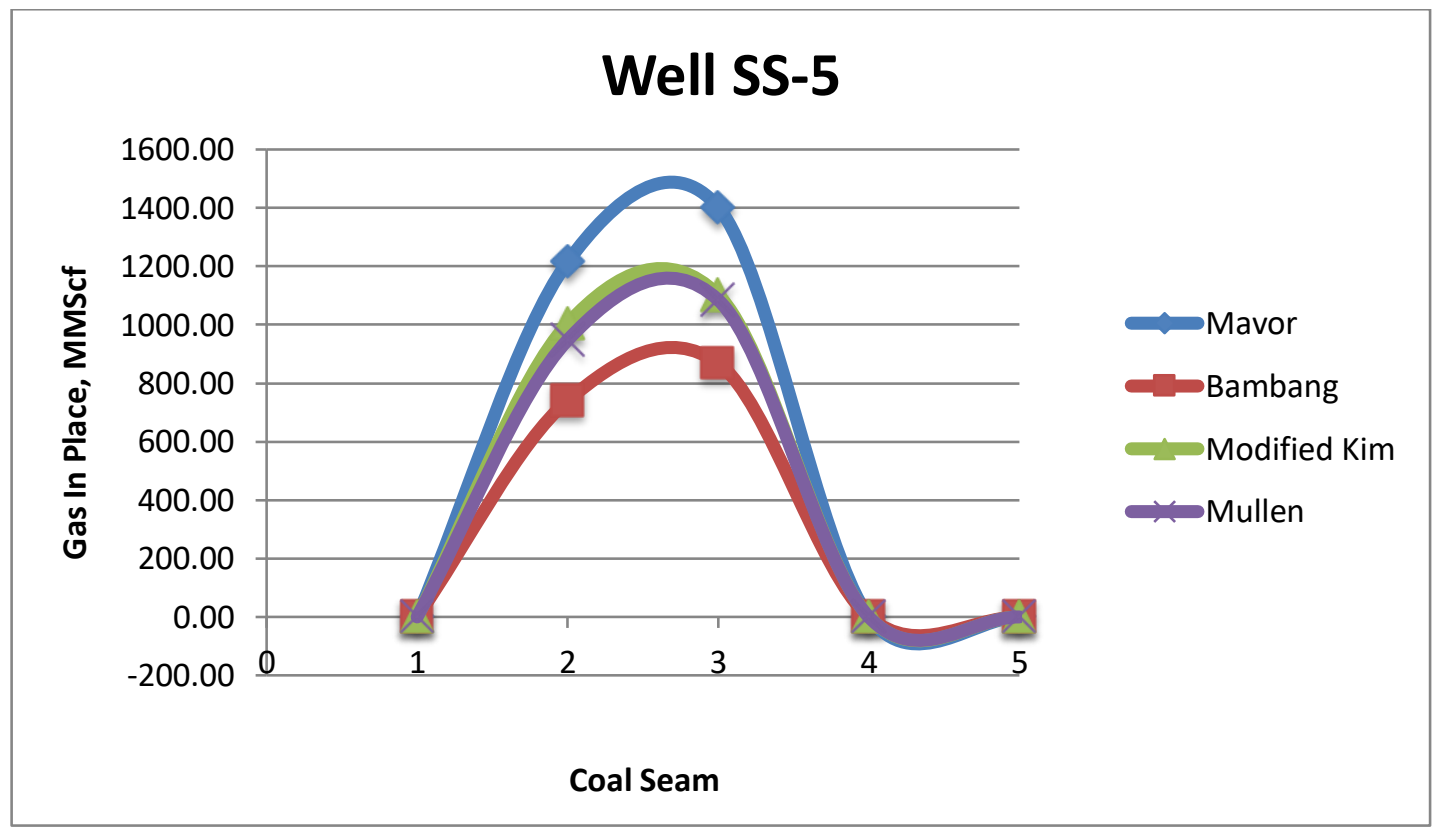

Fig. 5

GIP comparison at SS-5 wells 
Journal of Mechanical Engineering and Mechatronics

ISSN: 2527-6212, Vol. 3 No. 1

(C) 2018 Pres Univ Press Publication, Indonesia

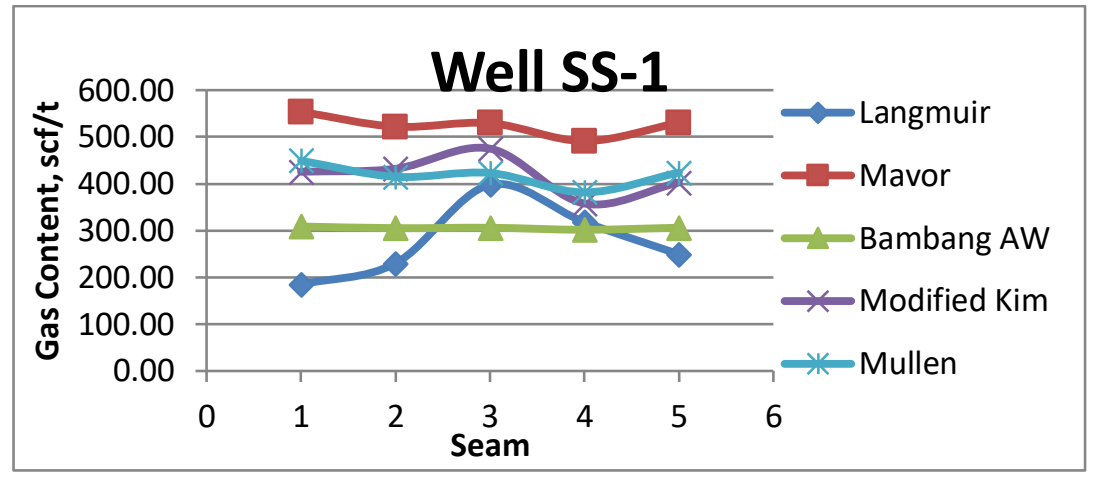

Fig. 6

Gas content comparison at SS-1 wells

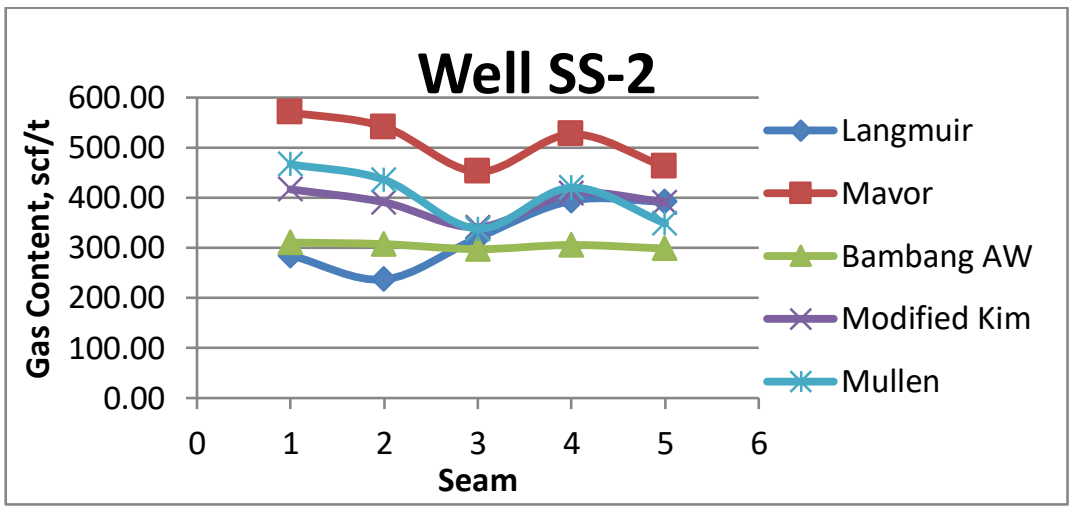

Fig. 7

Gas content comparison at SS-2 wells

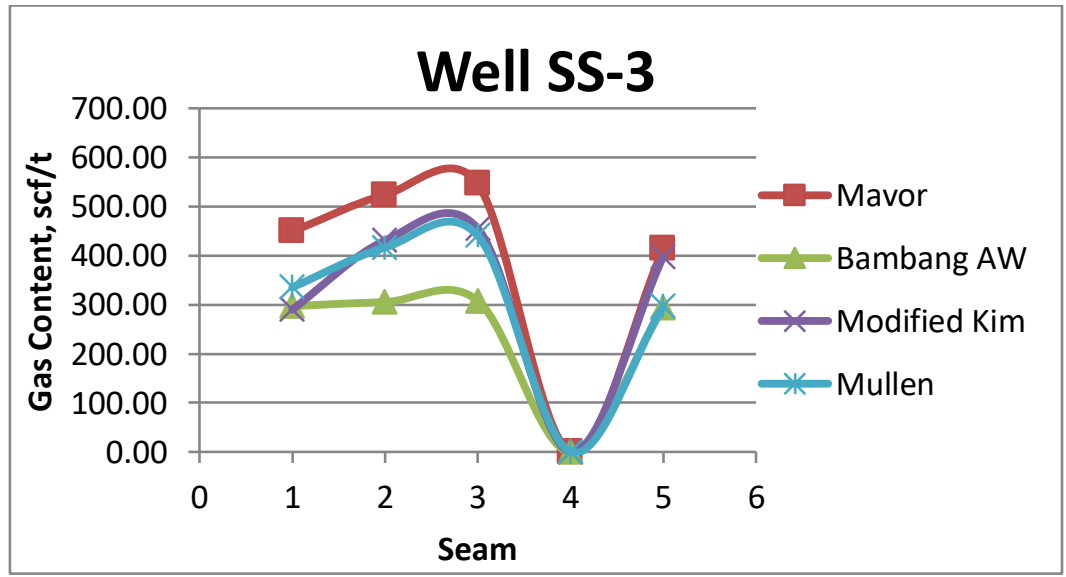

Fig. 8

Gas content comparison at SS-3 wells 
Journal of Mechanical Engineering and Mechatronics ISSN: 2527-6212, Vol. 3 No. 1

(C) 2018 Pres Univ Press Publication, Indonesia

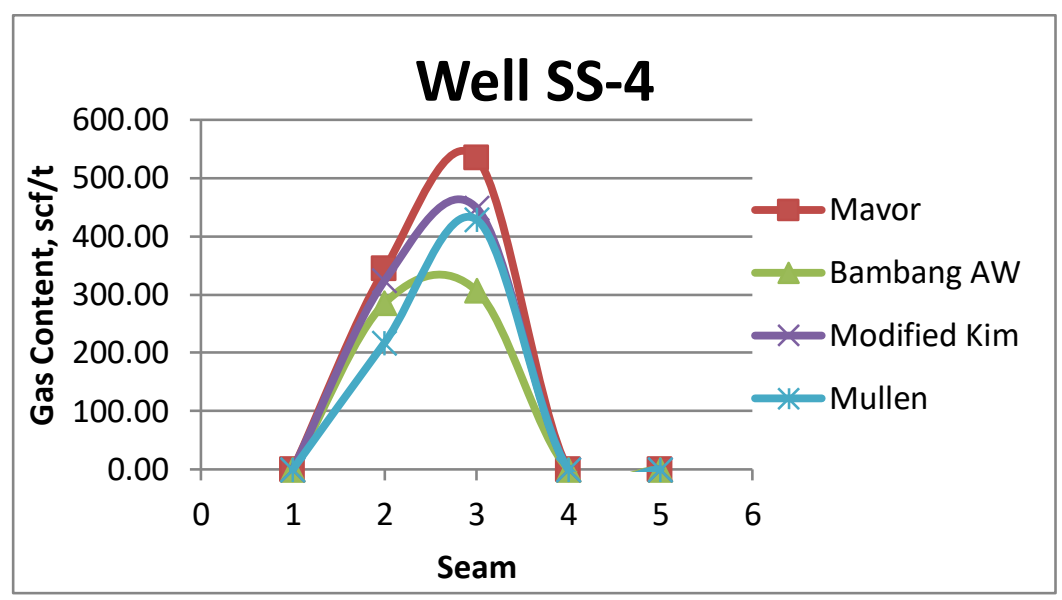

Fig. 9

Gas content comparison at SS-4 wells

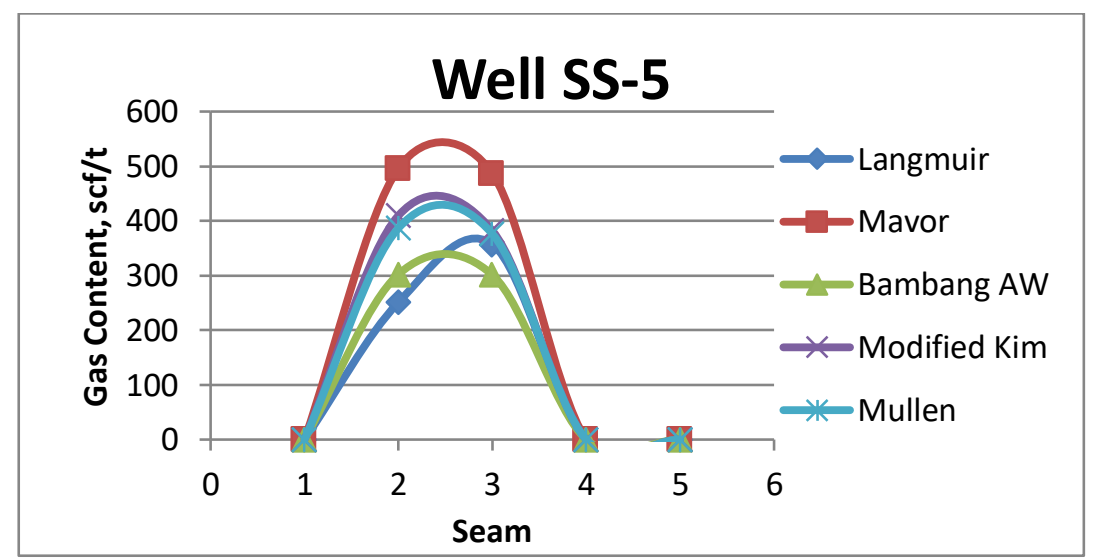

Fig. 10

Gas content comparison at SS-5 wells 